\title{
FRENCH ASSOCIATION FOR THE ADVANCEMENT OF SCIENCE
}

\section{Liege Meeting}

IN response to the kind invitation of the University of Liège, the French Association for the Advancement of Science met during July 17-22 for the third time in Belgium; the previous meetings were at Liège in 1924 and at Brussels in 1932.

The International Water Exhibition at Liège which marked the inauguration of the Albert Canal gave the meeting a special interest. Prof. C. Fabry, president of the French Association, presided over the meeting, and Prof. Dehalu, administrateur. inspecteur of the University of Liège, was president of the local committee.

The opening ceremony took place on July 17 in the hall of the University. Prof. Dehalu expressed his pleasure at receiving the Association at Liège for the second time, and Senator Buisseret, speaking on behalf of the burgomaster, weleomed the members of the congress. Prof. C. D. Ellis, Wheatstone professor of physics at King's College, London, representing the British Association, and Dr. C. Romaña, representing the Argentine Association for the Advancement of Science, brought messages of good will for the success of the meeting. Prof. Fabry, after having expressed the thanks of the Association to the local committeo at Liège, delivered his presidential address, on interstellar space.

Prof. Fabry showed how a profound study of the light of the stars has enabled us to detect, in interstellar space, matter in a state of extremo rarefaction ( $1 \mathrm{kgm}$. nearly in a volume equal to that of the earth). In addition to matter, there exists also in interstellar space energy in the form of radiation emitted by the stars. These results have demonstrated the fruitfulness of collaboration of diverse scientific disciplines and of pure and applied science. Such collaboration is also the object of the French Association and of similar bodies.

The scientific meetings were held in the magnificent Institutes of Civil Engineering and Chemistry of the University of Liège at Val Benoit on July 17 and the following days. July 19 was devoted to an excursion on the Albert Canal and to a visit to a colliery at Beeringen. July 21, the day of the national fête of Belgium, was taken up with a visit to the Water Exhibition.

The several sections of the Association showed great activity. The question of water occupied a prominent place in the programme, and was the subject of the following papers: M. Wyart, the states of solid and liquid water studied by X-rays; II. Cabannes, the Raman spectrum of liquid water; M. I Kraft de la Saulx, history of the construction of hydraulic machines ; M. Tongas, thermodynamic properties of steam ; M. Trochon, microphysics of mists considered as aerosols ; M. Roulleau, hygrometry ; M. Rocard, kinetic theory of liquids; M. Hubault, pollution of waters, their industrial utilization and modifications of their fauna.

The Section of Civil and Military Engineering, under the presidency of M. Campus, was divided into three subsections : theoretical and applied hydraulies; navigable channels and ports; hydraulic works. One session was devoted to colonial hydrography.

The Section of Physics heard communications, among others, from Profs. F. Joliot and F. Perrin. The work of the Section of Geology was completed by field excursions; the Section of Botany also had excursions in which the Royal Society of Botany of Belgium and the Liègo Botanical Circle joined.

The Sections of Biogeography and of Zoology held several joint sessions, with papers on the biology of equatorial lakes (II. Damas), the relations between the internal and external media in aquatic animals (M. Florkin), and the phreatic fauna (MI. R. Leruth).

Mention should also be made of the communications presented to the Section of Geography (streams, their utilization and management, demographic and social aspects of water); and to the Sections of Medical Sciences (metabolism of water), of Psychology and Pedagogy, of Radiology and of Odontology.

Special subsections considered technical applications of water, applications of electricity, archæology and folklore.

The communications presented at the meeting will form a special volume published in connexion with the Liège meeting.

The French Association will meet in 1940 at Nice, some time in July, under the presidency of Prof. Pieron, professor at the Collège de France, and director of the Institute of Psychology of the Univer. sity of Paris.

\section{SOCIAL AND INTERNATIONAL RELATIONS OF SCIENCE}

$\mathrm{T}$ HE first annual report of the Division for the Social and International Relations of Science of the British Association, founded by resolution of the General Committee of the Association in August 1938, was presented at Dundee and is printed with the Report of Council of the Association.

A statement of the aims and objects of the Division, together with a request for information on any work in the field of social relations of science, was circulated to some three hundred and fifty associations, institutions and learned societies in the British Isles and abroad. The replies received indicated that much work of this nature has been done, or is in progress, and in certain instances opportunity has already been found for the Division to exercise its function of co-ordination. Many offers of co-operation were received from bodies particularly interested in the social impacts of science, and several valuable 
contacts have been made. Notably, the Division learned that P E P (Political and Economic Planning) proposed to prepare a report on the organization of research in Great Britain, but was hampered by lack of funds to start the work. The Council of the Association, at the instance of the Divisional Committee, voted $£ 100$ as salary for the research worker appointed by $\mathrm{PEP}$ to collect the factual material. This enabled the work to proceed immediately, pending the acquisition of funds to maintain the inquiry from other sources. The necessary support has since been obtained from the Leverhulme Trustees, who have made available sufficient funds to carry on the inquiry until the autumn of 1940. The Division is represented on the committee supervising the work and will be associated with the report to be published in due course.

Some of the topics submitted to the Division for attention were referred to sections of the Association, and as a result several discussions and papers were arranged for the Dundee meeting.

A number of sub-committees have been appointed to deal with specific aspects of the Division's activities. One of these is considering the desirability of supplementing existing national research organizations whether in normal circumstances or in times of emergency. With tho viow of ascertaining details concerning systems of controlling and distributing grants in aid of research in other countries, an inquiry was directed to correspondents in the United States, France, Belgium, Holland, Denmark and the Dominions. Memoranda have been prepared by Prof. A. C. G. Egerton, and by Prof. J. D. Bernal and Dr. Julian Huxley, respectively, dealing with expendituro of public funds on research and discussing the question of a Research Co-ordination Council.

The sub-committee on nutrition and agriculture was responsible for a meeting at Reading to discuss milk in its nutritional and allied aspects. A resolution put forward from this meeting to the Council of the Association runs as follows :

"In view of the proved danger of the spread of epidemic and other diseases by the consumption of raw milk, of the efficiency of controlled pasteurisation in abolishing this danger and of the slight damage to the nutritive and other properties of milk caused by effective pasteurisation, it is essential for the national health that it be made compulsory in all urban areas with a population of 20,000 or more to pasteurise effectively all milk before sale to consumers to ensure its safety and to assist in securing that increase in the per capita consumption of liquid milk which is essential for improvement in the national lovel of nutrition." The Council, after consideration and consultation with the Nutrition Sub-Committee, considered it desirable that before taking any action on this resolution, a factual report on the whole question of the pasteurisation and sterilization of milk should be procured, and steps are being taken to do this.

Other sub-committees have been appointed to consider the economic requirements of nations, the influence of scientific and technical developments on industry, and on social psychology.

A Finance Sub-Committeo mado a recommendation to the Council of the Association that consideration should be given to the desirability of an appeal for funds to $(a)$ private individuals and firms, $(b)$ trusts at home, (c) trusts abroad, (d) H.M. Government. The Council adopted this recommendation, with the provision that of these possible sources, the first. named should be first explored.

Meetings arranged by the Division wore held during the past year at the University of Reading, in London at the Royal Institution, and at the University of Manchester.

\section{RADIO EXHIBITION, OLYMPIA}

$\mathrm{T}$ HE exhibition of radio apparatus organized annually by the Radio Manufacturers' Association was opened at Olympia on August 23 and is remaining open each weekday until September 2. This year's exhibition was conspicuous for the greatly increased attention and interest devoted to television receivers and also to several somewhat novel features which had a strong appeal to the more technically minded members of the public.

As regards the general display of sound broadcasting receivers, no fresh and outstanding change in technical design was in evidence this year. The large variety of models shown indicated that manufacturers have devoted attention for once to a steady improvement in efficiency and reliability, and the listener who is more concerned with service than with novelty may be assured that he can buy a new set with complete confidence. Most manufacturers now supply some form of 'push-button' tuning selection as part of one of their standard designs. A notable increase in the number and variety of portable receivers shows that there is a maintained demand for this type, and an innovation this year is the portable receiver operated entirely from dry batteries. This is the result of the introduction during the past year of new types of valves with a very low filament current consumption, so that a complete receiver may be operated under normal average conditions for several months, without changing or re-charging batteries.

It was in the field of television that the most marked change was evident in this year's exhibition of receivers. Most manufacturers' are now in a position to supply several types of television receivers, and these range from the table model with a small although very clear picture, up to an imposing cabinet model with a picture size about 24 in. $\times 18$ in. In all cases frequent daily demonstrations were given on the manufacturers' stands, while, in addition, a specially arranged 'television avenue' enabled the visitor to inspect some fifty different models in operation on the same programme and so judge their relative merits. Considering that, so far, telovision reception is limited in Great Britain to the programmes radiated from the one station at Alexandra Palace, the prospective purchaser of a receiver was very well catered for at the exhibition.

Among the conspicuous features of the layout of this year's show were the uniform flat-roofed stands, and also the models of Broadcasting House and the 